\title{
Loss of Value Bundo Kanduang in the Attention of Parents Who Affect Stress in Young Stunting
}

\author{
Eravianti $^{1}$, Delmi Sulastri ${ }^{2}$, Adang Bachtiar ${ }^{3}$, Yantri Maputra ${ }^{4}$ \\ ${ }^{1}$ Doctoral Program in Public Health Sciences, Andalas University-Indonesia, ${ }^{2}$ Professor of Biomedical Science, \\ Andalas University-Indonesia, ${ }^{3}$ Professor Association in Public Health Sciences, Indonesia University-Indonesia, \\ ${ }^{4}$ Professor Association of Psychology, Andalas University-Indonesia
}

\begin{abstract}
Research goals to know the stress and stress risk factors of a parent's attention to the loss of value Bundo Kanduang. Sampling techniques by purposive sampling. Data collection is conducted in the in-depth interview, observation of participation, and secondary data. The Number of subjects 5 people. The research was conducted in March 2020. The subject of youth research stunting Padang. The attention of parents is the dominant factor in causing stress. Based on the results of qualitative research of 5 informants. If parents' attention is good then low child stress levels For example children can control emotions, control themselves, be calmer when facing problems, easily socialize with the surrounding environment as well as vice versa. The loss of the value of Bundo Kanduang in the attention of parents greatly affects the stress experienced by teenagers. From qualitative analysis, 5 informants say the parents ' attention to risk factors related to stress.
\end{abstract}

Keywords: Stress, attention of parents, family, stunting, padang.

\section{Introduction}

Teenagers are the ages at which someone wants to try new things. So everything about the Internet can attract attention. With a big interest, then the desire to explore itself will be great too. The desire to be known and noticed by many people through the Internet. This can lead to negative behaviours. For example, writing something that belongs to someone else's privacy, uploading someone else's inappropriate images, can even make fun of your friends in social media. Dismissive behaviour, insult, or misled someone on the internet is included in cyberbullying or violence in cyberspace (Internet) ${ }^{1}$.

Technology contributes to adolescent mental health. The use of social media is one cause of stress in teenagers. The prevalence of stress and depression continues to

\footnotetext{
Corresponding Author:

Eravianti

Doctoral Program in Public Health Sciences, Andalas

University-Indonesia

e-mail: eraviantiunand@gmail.com
}

increase among adolescent generations. The prevalence of emotional mental disorders in teenagers over 15 years old amounted to $9.8 \%$. This figure increased compared to 2013 by $6 \%$. In West Sumatera Province, $4.5 \%$ of adolescents experienced emotional mental disorders. Emotional disorders occur in the form of stress, anxiety, and depression. As many as $25 \%$ of teenagers experience mild depression and $7 \%$ of teenagers with growing depression have attempted suicide attempts ${ }^{2}$.

Poor mental development such as easy stress on teenagers is exacerbated by stunting. Nationally, the stunting prevalence of 2018 years of stunting in Indonesian adolescents decreased to $25.7 \%$ (7.2\% very short and $18.5 \%$ short) in groups of aged $13-15$ years and $26.9 \%$ ( $4.5 \%$ is very short and $22.4 \%$ short $)$ in groups of age 16-18 year. The prevalence of stunting in adolescents in West Sumatra in 2018 the prevalence of stunting is almost equal to the national number of $25.6 \%$ (very short $7.2 \%$ and short $18.4 \%$ ) In the age group of $13-15$ years and $26.8 \%$ (very short $3.7 \%$ and short $23.1 \%)$ In the age group of $16-18$ years ${ }^{3}$.

Young stunting is more stress-prone than not stunting. Stunting sufferers are significantly less happy, depressed, and frustrated. Stunting has associations with 
increased cortisol concentrations. According to study 4 in Jamaica in children aged 8-10 years showed that the concentration of saliva cortisol was higher than that of normal children. Family roles and support are crucial in overcoming stress. If teenagers don't get the attention of parents, a problem is easy, because there is no telling of the youth.

Many factors are causing stress on adolescents, one of which is a factor of parental attention. Pressure in the family is one source of the stress of teenagers. The need for parent and adolescent cooperation in assisting the youth faced by teenagers, parents' attention is very main in addressing adolescents' problems especially stressing the quality Improvement Program of education through the improvement of high intensity-enriched curriculum, longer formal learning period, more school assignments and the necessity of becoming a leading centre has been stressful among adolescents. Young people suggest that they experience stress due to the lack of attention to parents ${ }^{5}$. Research is conducted to find out the stress and stress risk factors in the family in stunting adolescents.

\section{Method}

Research is done to 5 informants. Data retrieval was conducted in March 2020. The scope of research is included in the youth health sphere. This research is a qualitative study with a descriptive approach. Qualitative method can make it easier for researchers to describe the parents' attention factors affecting young stunting stress. This research sample is the teenage stunting of Padang City which meets the criteria of inclusion. The study subject chosen by the Purposive sampling method chosen is not random but is based on a particular consideration made by the researcher himself, i.e by the criteria of the inclusion of the established researchers. The number of subjects is 5 informants, students, parents, teachers, psychologists, and Bundo Kanduang. The free variables in this study are stressful. The Variables tied in this study are the concern of parents. Variables of parents' attention are obtained through a direct interview indepth interviews with the informant. Each informant is interviewed from a validated researcher's question. Data analysis is done along with the data collection process. The data analysis process begins with collecting all the interviews and observation data directly.

\section{Results}

Qualitative analysis results are aimed at knowing the parental attention factor as a risk factor for adolescent stress. Qualitative data collection is done with an indepth interview with some informants. In this qualitative study obtained the total informant of 5 persons in Table 1 below.

Table 1: Characteristics of qualitative research informant

\begin{tabular}{|c|c|c|c|}
\hline Code of Informant & Gender & Position & Age \\
\hline Inf. 1 & Female & High school students & 16 years old \\
Inf. 2 & Female & Parents 'student & SMK Teacher \\
Inf. 3 & Female & Psychologist & 50 years old \\
Inf 4 & Male & Bundo Kanduang & 30 years old \\
Inf 5 & Female & 66 years old \\
\hline
\end{tabular}

Source: Data analysis, 2020.

The attention of parents is the most dominant factor in causing stress based on qualitative research results. If parents' attention is good then the child's stress levels are low for example the child can control emotions, control themselves, be calmer when facing problems, not alone, easily socialize with friends and surroundings. Likewise, conversely if parents' attention less then the stress of a high child that means children are difficult to hang out like to be alone, often cry, do not concentrate on learning, easy emotions, often daydream, feel worthless, and so forth.
Based on information from students it is known that the attention of less or too excessive parents can cause stress such as the following statements "But yes, sometimes there is good and not good. Too much attention is also not good, to the point that when I want to take an exam I am told to study continuously, sometimes I get tired myself, I want to take a break first. But it's better to do it so that the enthusiasm for learning. It's a pity for those whose parents are too ignorant, but it's good to be in the middle (in terms of parental attention), who are just doing it. Being watched but not restrained (Inf-1)". 
The same information is also stated by parents that the child's attention should be reasonable and not excessive, by the following statements "Attention is important. Sometimes these mothers pay attention too much or are sarcastic, but that includes that attention, more like organizing it also includes attention. It's just that later the children won't be independent, that's all they need attention. It needs that attention to a reasonable degree (Inf-2)".

The same is stated by teachers that parents' attention affects the child's learning process, such as the following statement "There's no way a child can get good grades if the parents don't pay attention to the learning process ... ... indeed a child gets attention from parents, then their parents' background also has the education, then their economy is stable, the child is better (Inf-3)".

The attention that parents give to their children must be sufficient and reasonable. Excessive attention makes the child depressed and unnoticed to make the child feel uncherished. It by the statements of students and parents as follows "In my opinion, the attention is sufficient, not excessive and insufficient. Also not restrain so the child feels depressed. Parents must know the nature of their respective children, right? So, just adjust how the attention is (Inf-2)".

Teenagers are the time of transition from children towards adults up to their young people as a story of telling them, the attention of good parents will make the child feel comfortable and open to tell his problems. The children are not guided in patience not by being haunted or divided with problems that occur. It suits the following statements "Parents have time for their children, not too busy just to work because children also have problems that cannot be solved by themselves. Parents pay attention, not in the form of yelling, but what guides the child to better understand what the parents mean (Inf-1)".

At the Minangkabau community, the attention of a good mother is closely associated with the values and the role of the Bundo Kanduang. Minang people are not familiar with the figure of Bundo Kanduang as the first Madrasah child in the family than the father figure. Bundo Kanduang is a figure of educators and observers in the family even broadly for his people according to the following statements "Bundo Kanduang is closely related to women. The role of Bundo Kanduang in the family is of course inseparable from how to educate children, even to the extent of educating their families. Not only their biological children, to their families too. In a brief sense, Bundo Kanduang is a mother figure who not only educates her children but can also educate her people (Inf-3)". "The values adhered to by Bundo Kanduang are like guiding children with love (Inf-4)".

Bundo Kanduang is a symbol of indigenous women in Minangkabau. Bundo Kanduang is a designation for the mature Minangkabau woman and understands the customs. The following are the opinions regarding the Bundo Kanduang, according to the following statement "If there are mothers who are considered to be able to protect, not from their families, usually, it is determined from the community, it is agreed by the community who becomes Bundo Kanduang who can solve problems, who can be asked for advice (Inf-2)".

Now the role of Bundo Kanduang is necessary for educating the child, the attention of good parents according to the teachings of the Bundo Kanduang according to the following statement "Women as direction/advisors, women become the upstream and estuary of the problems of their people. Because this principle states that parents are a place for everything, a place to ask questions, to tell stories and to educate and guide children (Inf-5)".

Bundo Kanduang plays an important role in educating the child, but not just the mother in the house but has an important role in the community, but the role and values of this Bundo Kanduang Bundo have begun to disappear. Today mothers are busy working and leaving cultural values that should be retained according to the following statement "Parents are sometimes busy alone, children too. No more communication (Inf-2)".

Every Minang woman has the role of being a Bundo Kanduang in educating the child. In addition to mothers, children can be educated by their grandmother and challenge who also know the sublime values of Bundo Kanduang. In ancient times children lived in large families so much attention was received, but at present, there was only a core family consisting of mother and father alone. So the less attention of parents will be very influential to the child's stress. This corresponds to the following statement "Previously, the name of educating children was inseparable from the mother alone, there were her grandmothers, grandparents, her mother. If now they have lived alone (Inf-3)". 
Here is the opinion of the informant to revive the role of the Bundo Kanduang in addressing the child's problem, according to the following statement "The concept of Bundo Kanduang has been running for a long time and has been implemented in West Sumatra P2TP2A, PUSPAGA and other educational organizations. This concept should also be applied in PAUD schools, kindergartens and other formal schools (Inf-4)".

Based on information from students it is known that the attention of less or too excessive parents can cause stress. The same information is also stated by parents that attention to the child should be appropriate and not excessive. The same is stated by teachers that parents ' attention affects the learning process of children. Adolescent depression can be triggered by events that are often associated with family problems and conflicts. Stressful events and lack of social support from peers and family can also trigger the emergence of depressive conditions in adolescents ${ }^{6}$.

The presence of social support, especially from parents, will provide physical and psychological comfort for children. Families can act as social support providers that help individuals when a problem arises ${ }^{7}$. Individuals who gain high social support will be more optimistic and more able to adapt to stress ${ }^{8}$. The support that families can provide can be emotional, award support, tool support, and informative support ${ }^{9}$. This research is in line with ${ }^{10}$ research as the effect of the parent's attention towards student stress levels that there is a parental concern with a student stress level of 2017 with a P-value of 0.000 and a correlation value of coefficient 0.549 included in the moderate relationship level ${ }^{10}$.

As a parent should pay attention to his children, such as preparing breakfast, providing learning facilities, giving motivation, giving guidance to the child because in the childhood children began to grow and the child began to seek his identity, then the need for support and motivation from parents. Busy parents tend to be more concerned with the work than to gather with their children and do not give more attention to their children then the child will feel uncared for. As young children desperately need the attention and affection of their parents, it makes them more meaningful and more confident to actualize themselves ${ }^{11}$. From interviews with teachers and parents it is known that attention is important and needed by the child, but because the condition of a busy parent with work makes parents' attention to the child become not optimal. Interviews with teenagers are also known that they need parents' attention to encourage them to learn.

The attention of parents is good then low child stress levels For example children can control emotions, control themselves, be calmer while facing problems, not alone, easily socialize with friends and surroundings. And vice versa if the attention of parents less then the stress of a high child that means children are difficult to hang out like to be alone, cry, do not concentrate on learning, emotions, often daydream, feel worthless and so forth ${ }^{12}$.

The attention of parents in terms of the Bundo Kanduang is greatly reduced, because of the current aspects of the Bundo Kanduang administration, its nature to help guide the child in the Minangkabau region. So, it's the attention of parents is also reduced because of the teachings of the Bundo Kanduang that do not cling anymore to parents ${ }^{13}$. The interview results from 5 informants, especially in terms of the role of Bundo Kanduang, have been greatly applied outside the home or inside the house, especially when teenagers are now influenced by modern culture and the use of gadgets and the world of the internet.

\section{Conclusions}

Qualitative analysis obtained statements from 5 informant says that the risk factors of parental attention are related to stress.

Acknowledgements: The author says with a big thank you to the intellectual association "Bundo Kanduang" Padang City who has appointed me as the team leader and provided assistance in the research of "Loss of value Bundo Kanduang in the attention of parents who affect stress in young Stunting".

Ethical Clearance is taken from the institutional ethical committee of Andalas University-Indonesia as per rules.

\section{Source of Funding: Self}

\section{Conflict of Interest: Nil}

\section{References}

1. Priyatna, A. Let's End Bullying: Memahami, Mencegah, dan. Mengatasi Bullying. Jakarta: PT Elex Media Komputindo, 2010.

2. Kementerian Kesehatan (KEMENKES). Riset 
Kesehatan Dasar; RISKESDAS 2013. Jakarta: Balitbang Kemenkes RI. 2013.

3. Kementerian Kesehatan (KEMENKES). Riset Kesehatan Dasar; RISKESDAS 2018. Jakarta: Balitbang Kemenkes RI. 2018.

4. Fernald, L.C and Grantham-McGregor, S.M. Growth retardation is associated with changes in the stress response system and behaviour in schoolaged Jamaican children. The Journal of nutrition, 2002;132(12), 3674-3679.

5. Kwok, S.Y., Gu, M., Synchaisuksawat, P., and Wong, W.W. The relationship between parent-child triangulation and early adolescent depression in Hong Kong. Children and Youth Services Review, 2020; 109, 104676.

6. Nevid, S.F., Rathus, A.S., Greene, B. Psikologi Abnormal Edisi Kelima, Erlangga: Jakarta. 2003.

7. Videbeck, S.L. Buku Ajar Keperawatan Jiwa. Jakarta: EGC. 2008.

8. Mazbow. Apa Itu Dukungan Sosial. [Online].
Available: www.Mazbow.com. 2009, Accessed July 18, 2020.

9. Adicondro, N and Purnamasari, A. Efikasi Diri, Dukungan Sosial Keluarga dan Self Regulated Learning Pada Siswa Kelas VII. Humanitis, 2011;8(1), 18-27.

10. Khairani, S., Umari, T and Rosmawati. Pengaruh Perhatian Orang Tua Terhadap Tingkat Stres Siswa. Jurnal Online Mahasiswa Universitas Riau, 2017; 1-10.

11. Sunarti, E. Ketahanan Keluarga, Manajemen Stres, Serta Pemenuhan Fungsi Ekonomi dan Fungsi Sosialisasi Keluarga Korban Kerusuhan Aceh. Media Gizi \& Keluarga, 2005; 41-49.

12. Marques, A.H., Bjørke-Monsen, A.L., Teixeira, A L., Silverman, M.N. Maternal stress, nutrition and physical activity. Brain Research, 2015;1617, 28 46.

13. Ernatip, S.D. Kedudukan dan Peran Bundo Kanduang dalam Sistem Kekerabatan Matrilineal di Minangkabau. BNPB Padang. 2014. 